work of the chemical engineer during the past thirty-five years, and he urged that the situation should be examined constructively and with a view of helping rather than of controversy. He deprecated controversy over the relative merits of an education in the arts or in the sciences. This is a passing phase, although at present there are too many scientific illiterates, and it is regrettable that we should not have at the head of affairs, at a time of great technical improvements, more men with technical imagination capable of inspiring those working under them. Nor did Mr. Oriel think there is much advantage to be gained by comparing the position in Britain with that in the United States and the U.S.S.R. We do not wish to follow the U.S.S.R. in forcing men to adopt scientific or technological careers; but we cannot deny that we force men into National Service, and the Government has not grasped the seriousness of diverting from their profession when they are badly needed those chosen because of their ability for special training in science and technology.

Mr. Oriel thinks that the number of boys reading science has already increased, and that the quality will also improve. He believes that the technological sub-committee of the University Grants Committee will provide the necessary guidance and impetus to technological education, but pointed out that the universities can help to improve the status and outlook of teaching staff in the technical colleges by inviting their assistance in research and allowing more research carried out at the technical colleges to rank for the preparation of Ph.D. theses. He also suggested that universities hold on to their graduates too long; a university should retain only a very small number of those who have obtained their first degree, and only then after satisfying itself that they are really men who will benefit by a period in research, which normally, Mr. Oriel suggested, should be pursued at a different university. In general, the undergraduate after three or four years should move into industry or teaching, and those clearly designed for first-grade technologists should move elsewhere to a college also open to men who had already spent from two to five years in industry. In such institutions we may expect to find the interchange of ideas and techniques that will really make Britain a leader in quality of technologists. As regards the technical colleges, where the expansion in technical education will come, Mr. Oriel pointed out that the municipal or regional patriotism of the local education authority can be a source of strength as well as a weakness, and he appealed for full support of the 'sandwich' system by members of the Institution who as managers are in a position to help. Given such support and a right attitude by parents, teachers and university professors as well as industry, Mr. Oriel sees no reason why Britain should not double its output of well-trained scientists and technologists within five years.

Physical Society's Handbook of Scientific Instruments and Apparatus

Тне "Handbook of Scientific Instruments and Apparatus, 1956 Exhibition", published in connexion with the fortieth annual exhibition of scientific instruments and apparatus of the Physical Society, to be held in the Halls of the Royal Horticultural Society, London, during May 14-17 (see Nature, April 7 , p. 653), is not only a detailed catalogue and guide to the exhibits but is also a valuable reference book and useful indication to recent progress and development in the design and production of British scientific instruments and apparatus (pp. xvi $+257+$ 88 ; from the Society, at 1 Lowther Gardens, Prince Consort Road, London, S.W.7; $6 s$. or $7 s$. $6 d$. by post). It is arranged in the numerical order of the stands, totalling 131, which this year are to be housed in both the Old and New Halls of the Horticultural Society, thus giving much-welcome increased space for the display and demonstration of the exhibits. The exhibitors include, as formerly, government r'esearch establishments, universities, and scientific and technical publishers, in addition to about ninety-five manufacturers of scientific equipment. A brief description is given in the handbook of each particular item to be exhibited, in many cases also accompanied by an illustration, and a note is added to show whether the instrument or apparatus to be demonstrated is merely a prototype, is in production or can be made to order. The excellent indexes of both exhibitors and exhibits which preface the handbook will be found to be most helpful to users. To those who are unable to visit the exhibition, the handbook can be recommended as a comprehensive catalogue of modern physical apparatus and a quick reference book to the leading manufacturers. The advertisement section alone, consisting of eighty-eight pages, is in itself a most valuable collection of interesting information.

\section{British Chemical Engineering}

THE first number of British Chemical Engineering is attractive and readable (Drury House, Russell Street, London, W.C.2). There is always a place for commercial journals in engineering, which is commercial itself in essence. They will be read by engineers if they contain the news. The news is not solely a matter of research work, but of developing ideas, new emphasis, new invention and the plain story of what the other man is doing. The development of ideas in chemical engineering has shown a change since the War. The straight classification of techniques into unit operations has yielded to an insistence on fluid flow, heat and mass transfer as fundamental to them all. The strength of present design methods is shown in the first article on achievements at Windscale. These were made (and made better according to Sir Christopher Hinton) without benefit of pilot plant. This view is also put forward by Lincoln T. Work in the last article. The leader and editorial comments are well written and well informed. The criticism levelled at the lack of chemical engineering research in government stations is not founded on a careful study of the work going on, but on the annual report of the Department of Scientific and Industrial Research, which is condensed. Other articles are of a good standard and the features well planned. This is altogether a professional production and will need to maintain a level to justify a title which involves so much.

\section{Nematologica: New Journal of Nematological Research}

A NEW international quarterly journal of nematological researeh, Nematologica, has been founded through the initiative of Dutch workers, after informal discussion among some of the participants at the third symposium on plant nematology, held at Wageningen in July 1955. The editorial board 